July 21, 1991

Mrs. Diane Harrison-Giesler

Mr. Max Poweil

U.S. Department of Energy

Las Vegas, NV

Dear Diane and Max:

Enclosed please find the first part of our project report covering the period January - June 1991.

A full report detailing the research work of the project staff will follow in the coming month and will include two extensive studies of the canister top and pintle structures by Brett kniss, Los Alamos N.L. and Samaan Ladkany, UNLV and stress and displacement studies of a rock runnel under excavation and canister thermal loads, by Nadia K. Ladkany and Richard Wyman both of UNLV.

These studies were considered as part of Brett and Nadia's requirements for the degree of M.S. in Civil Engineering at UNLV.

sincerely,

Samaan G. Ladkany, Ph.D., P.E. Professor of Civil Engineering

Director of Waste Package Project

$\operatorname{sgl} / \mathrm{pjn}$ 


\title{
WASTE PACKAGE PROGRAM
}

\author{
PROF. W. CULBRETH AND S. LADKANY
}

\section{DISCLAIMER}

This report was prepared as an account of work sponsored by an agency of the United States Government. Neither the United States Government nor any agency thereof, nor any of their employees, makes any warranty, express or implied, or assumes any legal liability or responsibility for the accuracy, completeness, or usefulness of any information, apparatus, product, or process disclosed, or represents that its use would not infringe privately owned rights. Reference herein to any specific commercial product, process, or service by trade name, trademark, manufacturer, or otherwise does not necessarily constitute or imply its endorsement, recommendation, or favoring by the United States Government or any agency thereof. The views and opinions of authors expressed herein do not necessarily state or reflect those of the United States Government or any agency thereof. 
SIX MONTH PROGRES8 REPORT ON THE WABTE PACKAGE PROJECT AT THE UNIVERSITY OF NEVADA, IAS VEGAB

$$
\text { JANOARY } 1991 \text { - JUNE } 1991
$$

PRESENTED TO:

THE 0.8. DEPARTMENT OF ENERGY LAS VEGAB, NEVADA 


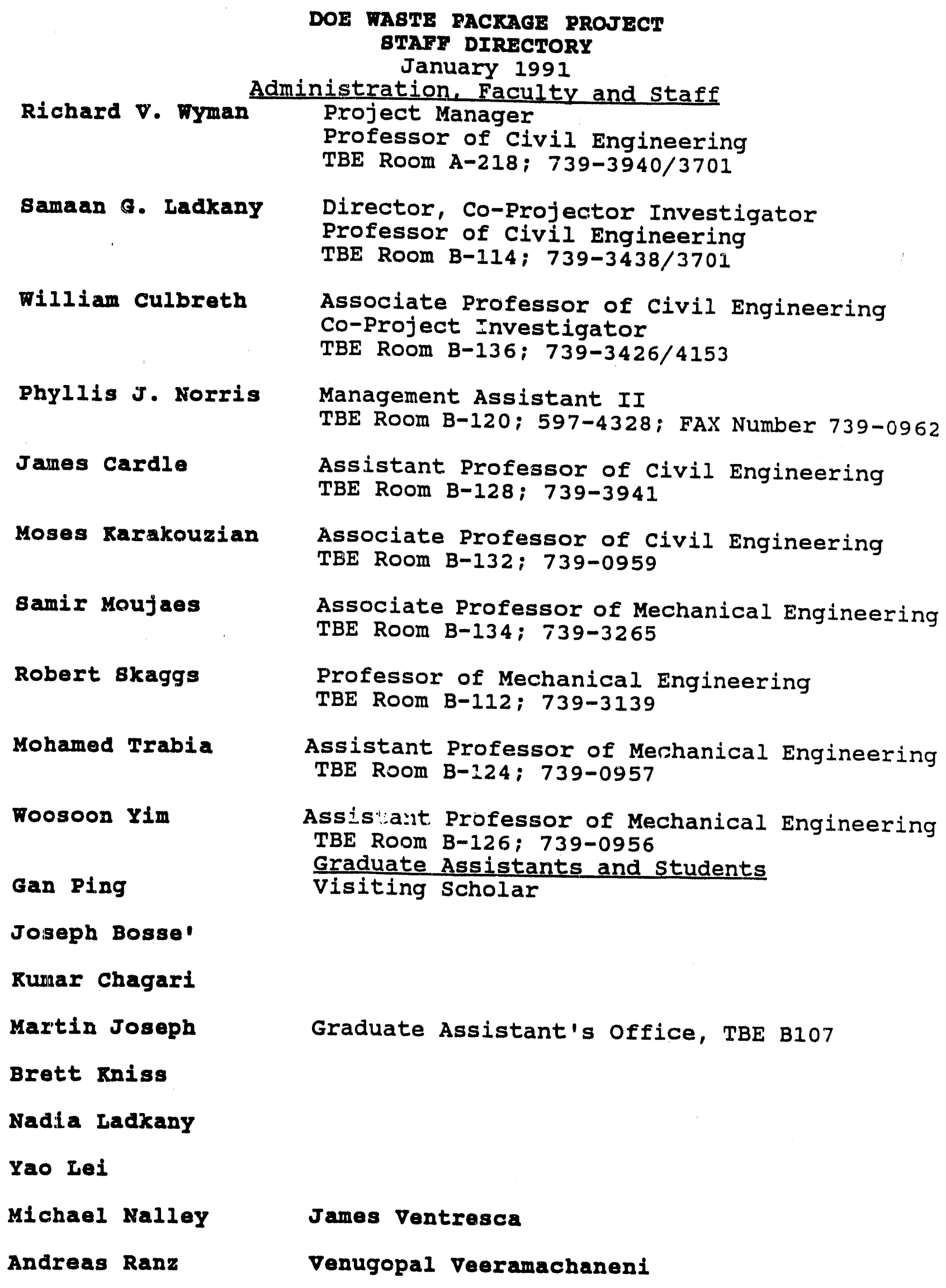

William Culbreth

Phyllis J. Norris

James Cardle

Moses Karakouzian

samir Koujaes

Robert skaggs

Mohamed Trabia

Woosoon Yim

Gan Ping

Joseph Bosse'

Kunar Chagari

Martin Joseph

Brett Rniss

Nadia Ladkany

Yao Lei

Michael Nalley

Andreas Ranz

Associate Professor of civil Engineering Co-Project Investigator

TBE Room B-136; 739-3426/4153

Management Assistant II

TBE Room B-120; 597-4328; FAX Number 739-0962

Assistant Professor of Civil Engineering TBE Room B-128; 739-3941

Associate Professor of Civil Engineering TBE Room B-132; 739-0959

Associate Professor of Mechanical Engineering TBE Room B-134; 739-3265

Professor of Mechanical Engineering TBE Room B-112; 739-3139

Assistant Professor of Mechanical Engineering TBE Room B-224; 739-0957

Assisiant Professor of Mechanical Engineering TBE Room B-126; 739-0956

Graduate Assistants and students

Visiting Scholar

Graduate Assistant's Office, TBE B107

\author{
James Ventresca \\ Venugopal Veeramachaneni
}




\title{
SIX MONTH PROGRES8 REPORT ON THE WABTE PACKAGE PROJECT AT THE ONIVERSITY OF NEVADA, IAS VEGAS \\ JANOARY 1991 - JUNE 1991 \\ MANAGEMENT, QUALITY ABgURANCE AND OVERVIEW
}

\author{
DR. SAMAAN G. LADKANY, R.E. \\ PROJECT DIRECTOR, CO-PI
}

I. Introduction and over view

The Waste Package Project was initiated by the DOE on June 17, 1990 under the UNLV/DOE cooperative agreement. Its initial period will cover one calendar year, renewable by mutual agreement.

The UNLV project staff will concentrate their research efforts on the literature surveys and data collection pertaining to the various design aspects of a waste package to be used for the long-term storage of high level waste in a geologic formation.

The project staff includes:

Dr. Samaan G. Ladkany, Professor and Director Dr. Richard Wyman, Professor and Manager Dr. William Culbreth, Associate Professor and PI 
Dr. Mohamed Trabia, Assistant Professor

Dr. Robert Skaggs, Professor

Dr. James Cardle, Assistant Professor

Dr. Samir Moujaes, Associate Professor

Ten Research Assistants

Phyllis Norris, Project Secretary

studies of the package near field phenomena, such as fluid transport and heat transfer through porous media, and the design and layout of rock tunnels will also be attempted by the project research staff.

II. Task Assignments for the Waste Package Project

The following personnel have been assigned to the various tasks outlined in the cooperative agreement document. Supplemental tasks listed in section B were agreed upon in the DOE,/INLV meeting held at 9:00-12:00 a.m., 11 July 1990 at UNLV. The university researchers are in contact with the relevant DOE contact persons discussed in the meeting to gain assistance as they progress with their studies.

\section{A. Required Tasks}

1. Management, Quality Assurance, and Overview

a. Insure training and quality requirements met. [Wyman, Ladkany ]

b. Overview of task \#2 [Ladkany]

c. Overview of task \#3 [Trabia]

d. Overview of task \#4 [Culbrethj

Project Manager: Dr. Wyman

Project Director: Dr. Ladkany 
2. Structural Analyses of spent Fueg and High Level Waste

a. Iiterature search of spent fuel cladding including current designs, past analyses, accident histories, and rupture analysis techniques. [Skaggs, Moujaes]

b. Literature search of container structural performance [Ladkany, Cardle]

Team Leader: Dr. Ladkany

Drs. Skaggs, Moujaes, Cardle

3. ASME Pressure Vessel Code Review for Waste Package Application

a. Assemble relevant codes to apply to waste package container.

b. Explore use of these codes to the waste package. [Trabia, Moujaes]

c. Library search for reliability/failure rates data on low P, low $T$ piping, containers, and casks with long design lives. [Moujaes, Cardle]

Team Leader: Dr. Trabia

Drs. Moujaes, Cardle

4. Waste Package Labeling

a. Literature search of labeling techniques. [Culbreth]

b. Form suggestions to DOE for further study, development, and testing. [Culbreth]

Team Leader: Dr. Culbreth

B. Supplemental Tasks

1. Structural Analysis and Design of Waste Package Container Team Leader: Dr. Ladkany

2. Optimum Design of Rock Tunnel Shapes 
Team Leader: Dr. Wyman

3. Fluid transport and heat transfer through porous media in the waste package near field environment.

Team Leader: Dr. Cardle

Drs. Culbreth and Cardle

III. DOE/8AIC Personnel Cooperating with Project Waste Package staff

The UNLV project staff have established a direct line of contact with the following DOE/SAIC personnel to insure a smooth and orderly progress of the Waste Package Project.

Mr. Max Powell, DOE

Dr. Michael Cloninger, DOE

Ms. Diane Harrison-Giesler, DOE, Project Monitor

John White, DOE

Mr. Richard Morisette, SAIC

Dr. Paul Cloke, SAIC

Dr. David Stahl, SAIC

your staff has established a one-to-one research

correspondence with various members of the DOE/SAIC group listed above in accordance with areas of shared research interests. IV. Organization and Equipment Acquisitions

A Materials Testing System (MTS) machine capable of precision stress-stain measurements in the axil-torsional modes is on order. The DOE supplied one-third of the cost $(\$ 70,000)$. Computer equipment, software and manuals have also been ordered $(\$ 29,000)$.

The project is in the process of creating a centralized 
facility for the storage of the impressive number of publications obtained from DOE, National Laboratories and EPRI. Project documents will be catalogued and stored in a manner that makes them accessible to the project researchers. The facility will also house the computer equipment and provide work space for project student assistants.

v. staff meetings with DOE personnel, tutorials and travels on behalf of project

Several meetings were held with our staff counterparts at the DOE to help in launching the project. A tutorial was given to our staff by DOE on July 5, 1990 and a budget meeting was held at UNLV on July 11, between the DOE personnel and Drs. Ladkany and Culbreth. The DOE personnel visited the UNLV research facilities and held a meeting with our staff and HRH College Dean William Wells on July 6. Drs. Wyman, Ladkany and Culbreth also attended the TPO meetings during summer and fall 1990 held in Las Vegas, on September 7, 1990 .

Drs. Ladkany and $C$ lisreth attended the DOE public hearings in Denver, Colorado and met with DOE personnel, while Dr.Skaggs attended a two week tutorial sponsored by NSF in Buffalo, New York in June 1991.

Dr. Ladkany attended a course on crack propagation in Washington D.C. sponsored by AIAA and Drs. Skaggs, Ladkany and Karakouzian attended a week of studies on experimental techniques at Sandia National Laboratories in Livermore, CA.

Dr. Ladkany submitted an equipment proposal under the Infrastructures co-operative research grant to the University of 
Nevada system.

Two graduate students received their M.S. degrees with partial funding from our DOE Project.

Brett Kniss, from Los Alamos National Lab, worked with Dr. Ladkany on the structural analysis and design of canister top and pintle.

Nadia Kandalaft-Ladkany from UNLV, worked with Dr. Richard Wyman on the stress analysis and displacements of rock tunnels due to excavations and thermal loading from the storage canisters.

Research meetings were held between Drs. Ladkany and Wyman and Trabia of UNLV and Drs. John White and Morisette of DOE, Drs. Skaggs, Moujaes and Cardle of UNLV, Drs. Stahl and cloke of SAIC.

Drs. White of DOE and Stahl of SAIC have been involved in course planning and teaching in areas related to our research work.

Drs. White, stähl and cloke have also been appointed as Adjunct faculty in the Civil Engineering Department and will contribute greatly in the growth of the nuclear and environmental programs in the Civil Engineering Department at UNLV.

The project staff held a meeting in March to which DOE counterparts were invited. The group discussed the progress of research and to date and the various ideas presented by the project researchers for further studies next year.

Drs. Ladkany and Culbreth attended the Engineering Barriers System Workshop in Denver, Colorado June 18-21. 
Important concepts for new storage canister designs were presented.

The panel of experts brought up valuable suggestions and critical points concerning the proposed design.

Our UNLV researchers will have to identify with the help of our DOE/SAIC counterparts, aspects of the proposed new designs for further studies by our project stafr.

Contacts will be made soon with DOE personnel to arrange for a meeting regarding this subject.

Following is a report covering the progress of our project research for the period of January to June 1991. 
DOE Semi-Annual Progress Report

"Supplemental Task B.1"

structural Analysis and Design of Waste Package Container

Dr. Samaan G. Ladkany and Brett Kniss

\section{Abstraots}

Efforts are directed towards the compilation of U.S. and International publications on the physical characteristics, material properties and design specifications of the waste package container. A variety of top head shapes witr pintles have been considered and analyzed for strength, weight saving, reliability and minimum weldment stresses. Stresses due to loading under operating conditions is studied.

Discussion

A brief discussion of some of the most pertinent sources available on waste containers in the literature is presented. Research dealing with design spezifications, loading conditions, stress concentrations at weldments and loading conditions under operating conditions have been collected to try to understand the collective thinking of international researchers dealing with the design of waste containers.

Present container designs are being criticized on the ground of long-term safety. This may result in a new and truly conservative design of the waste container in the future.

A variety of Top Head shapes have been considered in the analysis. These include; hemispherical, torospherical (ASME flanged and dished), flat, and ellipsoidal. These shapes will compare the advantages and disadvantages of carrying loads as bending stresses versus membrane stresses. The top head shape effect on stress 
concentrations in the weldment are presented. Areas of high stress concentrations eventually develop cracks that propagate through the weldment and the container walls over a long period of time. Even the smallest of cracks may result in the failure of the barrier system due to the stress corrosion cracking phenomena.

Studies show that the stresses in the weldment canister top and pintle are greatly influenced by the thickness and shapes of these structures relative to the thickness of the canister. 

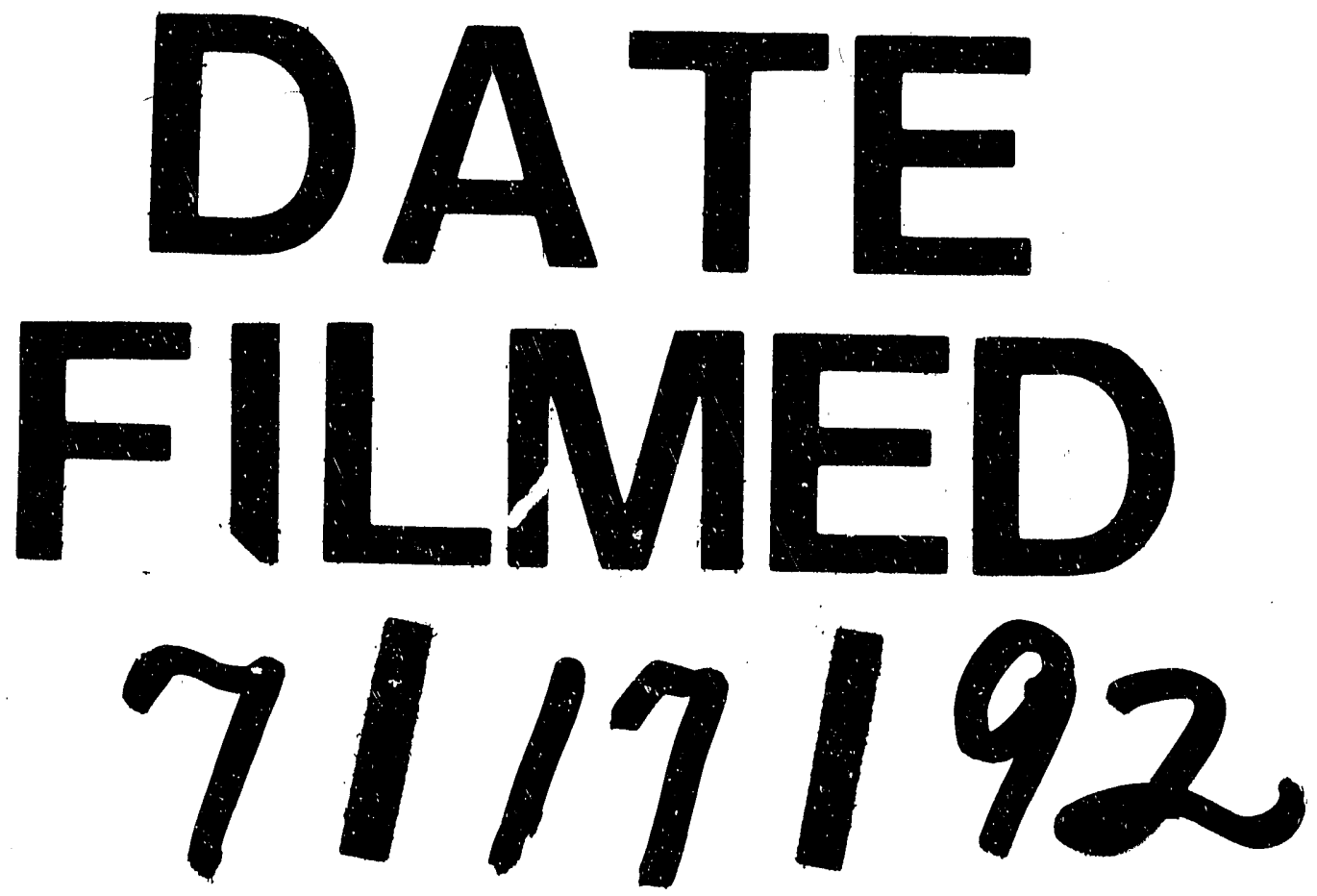

$\overline{\mathbf{F}}$

$\Gamma$ 
